\title{
UPAYA GURU DALAM MENINGKATKAN HASIL BELAJAR MATEMATIKA TEMATIK REALISTIK SISWA KELAS DI KELAS IV SD NEGERI 34 SUNGAI BELIDAK
}

\author{
ISKANDAR \\ SD Negeri 34 Sungai Belidak \\ e-mail: iskandarkakap5@gmail.com
}

\begin{abstract}
ABSTRAK
Tujuan penelitian adalah untuk mengetahui upaya guru dalam meningkatkan hasil belajar matematika tematik realistik siswa kelas di kelas IV dengan menggunakan Penelitian Tindakan Kelas (PTK) data diperoleh melalui observasi, dokumentasi yang berupa tugas-tugas siswa. Teknik analisis data dilakukan dengan teknik deskripsi kualitatif. Keberhasilan yang dicapai siswa dalam penelitian ini dilihat dari adanya peningkatan dalam tindak belajar. Hasil penelitian menunjukkan bahwa hasil belajar dapat meningkat setelah diberi tindakan melalui Pembelajaran Realistik. Hasil belajar kognitif pada pra tindakan menunjukkan bahwa sebanyak 3 siswa (20\%) telah mencapai KKM kemudian pada siklus I meningkat menjadi 8 siswa $(54,30 \%)$ dan pada siklus II meningkat menjadi 12 siswa (80\%). Hasil rata-rata sikap siklus I mencapai 59,30\% sedangkan siklus II diperoleh hasil rata-rata sikap sebesar 79,5\%. Dengan demikian, Pembelajaran Matematika Realistik dapat meningkatkan hasil belajar Matematika siswa kelas IV SD Negeri 34 Sungai Belidak
\end{abstract}

Kata Kunci: Hasil Belajar, Matematika, tematik, Realistik

\section{PENDAHULUAN}

Semakin berkembang kehidupan manusia, semakin berkembang pula permasalahan yang dihadapi pendidikan, sehingga semakin menuntut kemajuan manusia dalam pemikiranpemikiran tentang pendidikan. Kini semakin disadari bahwa pendidikan memainkan peranan yang penting dalam kehidupan dan kemajuan umat manusia. Pendidikan merupakan suatu kekuatan yang dinamis dalam kehidupan setiap individu, yang mempengaruhi perkembangan fisiknya, daya jiwanya (akal, rasa, dan kehendak), sosialnya dan moralitasnya (Dwi Siswoyo, dkk 2007: 17).

Proses pendidikan akan sempurna dan berhasil manakala prinsip-prinsip tertentu terpenuhi memang kadang-kadang proses itu mengalami sandungan kadang-kadang mengalami kegagalan bila prinsip tersebut tidak terpenuhi maka kita harus mempelajari metode yang digunakan dalam mendidik serta menanamkan prinsip dan nilai-nilai keislaman pada diri mereka niscaya dapat menggali beberapa prinsip penting yang berkenaan dengan proses pembelajaran yang digunakan (Sapri, 2018: 176).

Pendapat di atas mengungkapkan bahwa pendidikan merupakan usaha sadar dalam proses pembelajaran agar peserta didik dapat mengembangkan potensi dirinya secara aktif. Proses pembelajaran mengandung makna adanya kegiatan mengajar dan belajar, di mana pihak yang mengajar adalah guru dan yang belajar siswa yang berorientasi pada kegiatan mengajarkan materi pada pengembangan pengetahuan, sikap, dan keterampilan siswa sebagai sasaran pembelajaran.

Kemampuan yang tampak pada fase ini adalah kemampuan dalam proses berpikir untuk mengoperasikan kaidah-kaidah logika, meskipun masih terikat dengan objek yang bersifat konkret. Mata pelajaran yang dapat diterapkan dalam kehidupan sehari-hari salah satunya adalah matematika. Matematika dapat menyiapkan individu dalam meningkatkan taraf hidup dan memecahkan permasalahan yang dihadapi dalam kehidupan sehari-hari. Matematika telah diberikan sejak siswa di Sekolah Dasar. Hal ini menunjukkan bahwa matematika sangat penting dalam jenjang selanjutnya. Senada dengan pendapat Antonius Cahya Prihandoko (2006: 1) bahwa matematika merupakan ilmu dasar yang sudah menjadi alat untuk mempelajari imu-ilmu lain. Menurut Sri Subarinah (2006: 2), kegunaan matematika bagi siswa SD adalah sesuatu 
yang jelas yang tidak perlu dipersoalkan lagi, terlebih pada era pengembangan ilmu pengetahuan dan teknologi dewasa ini. Matematika dapat berfungsi mengembangkan keterampilan berhitung dengan bilangan sebagai alat dalam kehidupan sehari-hari.

Matematika merupakan mata pelajaran yang sulit dipahami sehingga siswa menjadi takut saat mendengar kata matematika (Ariyadi Wijaya, 2012). Oleh karena itu, penguasaan terhadap matematika harus diperlukan dan konsep-konsep matematika harus dipahami dengan betul dan benar sejak dini. Suatu konsep disusun berdasarkan konsep-konsep sebelumnya dan akan menjadi dasar bagi konsep-konsep selanjutnya, sehingga pemahaman yang salah dari suatu konsep akan berakibat pada kesalahan pemahaman terhadap konsep-konsep selanjutnya.

Matematika harus disajikan dalam suasana yang menyenangkan sehingga siswa termotivasi untuk belajar matematika. Beberapa upaya yang dapat dilakukan guru untuk menarik perhatian dan meningkatkan motivasi siswa dalam belajar matematika antara lain dengan mengkaitkan materi yang disajikan dengan konteks kehidupan sehari-hari yang dikenal siswa di sekelilingnya atau dengan memberikan informasi manfaat materi yang sedang dipelajari bagi pengembangan kepribadian dan kemampuan siswa untuk menyelesaikan masalah-masalah selanjutnya, baik permasalahan dalam matematika itu sendiri, permasalahan dalam mata pelajaran lain, maupun permasalahan dalam kehidupan sehari-hari (Tarigan, 2006).

Keberhasilan proses pembelajaran ditentukan oleh hasil belajar yang dicapai oleh siswa. Pembelajaran bukan menginformasikan materi agar dikuasai oleh siswa, tetapi memberikan kondisi agar siswa mengusahakan terjadi belajar dalam dirinya. Hasil belajar merupakan perubahan pada diri anak meliputi kemampuan intelektual, sikap/minat maupun keterampilan setelah mengikuti proses belajar mengajar. Kemampuan intelektual dapat diukur dengan tes hasil belajar. Siswa dapat dikatakan berhasil apabila telah mencapai Kriteria ketuntasan Minimal yang telah ditentukan pada mata pelajaran Matematika.

Berdasarkan hal tersebut di atas, ketepatan dalam pemberian pendekatan pembelajaran sangat menentukan hasil belajar siswa. Dengan pendekatan pembelajaran yang tepat, siswa dapat termotivasi dan senang dengan apa yang akan guru sampaikan. Penggunaan rumus-rumus matematika tanpa memahaminya hanya akan menjadi sebuah hafalan. Jika siswa mempelajari matematika hanya dengan hafalan, maka mereka tidak akan bisa menerapkan konsep atau rumus tersebut untuk menyelesaikan permasalahan sehari-hari yang mereka temukan.

Salah satu pendekatan pembelajaran yang dapat diterapkan dalam pembelajaran matematika adalah Pembelajaran Matematika Realistik. Menurut Tarigan (2006: 1), pembelajaran ini menekankan akan pentingnya konteks nyata yang dikenal murid dan proses konstruksi pengetahuan matematika oleh murid sendiri. Pembelajaran matematika realistik sebagai kegiatan yang lebih menekankan aktivitas siswa untuk mencari, menemukan dan membangun sendiri pengetahuan yang dia perlukan sehingga pembelajaran menjadi terpusat pada siswa. Matematika realistik pada dasarnya adalah pola belajar yang memanfaatkan realitas dan lingkungan yang dipahami siswa untuk memperlancar proses pembelajaran Matematika sehingga dapat mencapai tujuan pembelajaran Matematika secara lebih baik.

\section{METODE}

Indikator kinerja tindakan adalah aspek-aspek variabel yang akan ditingkatkan sebagai petunjuk (indikator) untuk mengukur hasil belajar siswa dan proses tindakan yang dilakukan, yang dalam hal ini terdapat dua veriabel. Hasil observasi dianalisis dengan analisis deskriptif. Penelitian ini dikatakan berhasil jika sudah terdapat $80 \%$ siswa telah tuntas mencapai nilai KKM. Prosedur Penelitian Tindakan Kelas (PTK) dapat dilaksanakan melalui empat langkah utama yaitu: perencanaan (planning), pelaksanaan (acting), pengamatan (observing) dan refleksi (reflecting). Empat langkah utama dalam pelaksanaan Penelitan Tindakan Kelas (PTK) sering disebut dengan istilah satu siklus (Susilo, Herawati.dkk, 2009:19). Untuk lebih jelas berikut ini dikemukakan model siklus Penelitian Tindakan Kelas (PTK): 


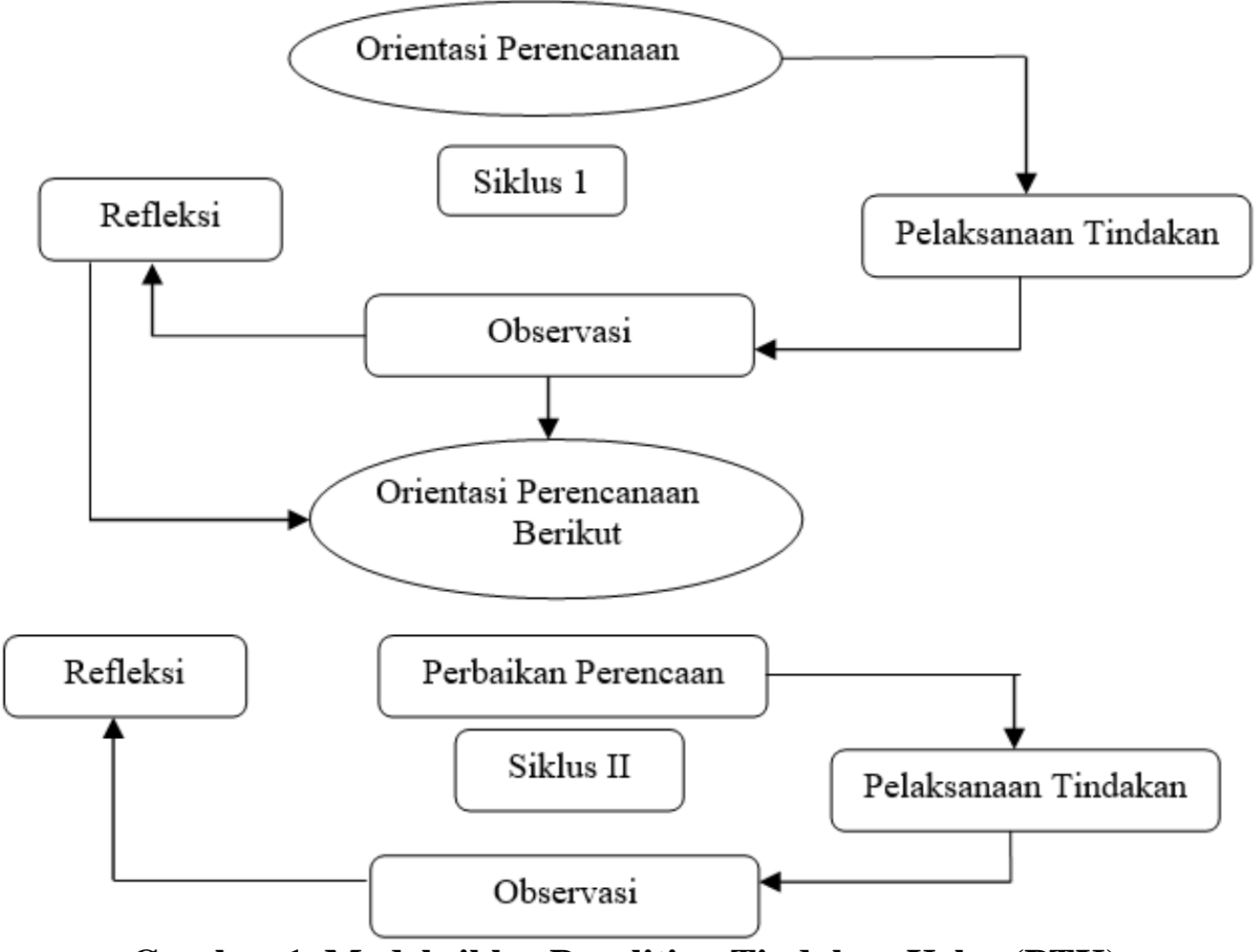

Gambar 1. Model siklus Penelitian Tindakan Kelas (PTK)

Pengumpulan data dalam teknik evaluasi adalah lembar soal/lembar tes yang akan dikelolah dengan teknik penskoran dan penilaian. Penskoran adalah suatu proses perubahan jawaban-jawaban tes menjadi angka-angka (mengadakan kuantifikasi). Sedangkan penilaian adalah proses menentukan nilai suatu obyek dengan menggunakan ukuran atau kriteria tertentu, seperti Baik, Sedang, Jelek. Angka-angka hasil penskoran itu kemudian diubah menjadi nilainilai melalui proses pengolahan tertentu. Cara menskor hasil tes biasanya disesuaikan dengan bentuk soal-soal tes.

\section{HASIL DAN PEMBAHASAN}

\section{A. Hasil Observasi pada Siklus I}

Observasi yang dilakukan pada siklus I meliputi dua pertemuan. Dari kedua pertemuan tersebut, guru telah melakukan semua aktivitas yang ada dalam lembar observasi. Observasi dilakukan bersamaan dengan berlangsungnya proses pembelajaran dengan menggunakan lembar observasi yang telah dibuat. Siklus I dilakukan sebanyak dua kali pertemuan. Pertemuan pertama adalah materi pengukuran debit dan waktu. Pada kegiatan awal, Peneliti mengawali pembelajaran dengan melakukan apersepsi kepada siswa. Tahap selanjutnya, guru memberikan pertanyaan mengenai masalah kontekstual untuk dipecahkan secara berkelompok. Peneliti meminta masing-masing kelompok untuk menyelesaikan masalah yang diberikan dengan cara mereka sendiri. Peneliti bersama siswa membahas hasil yang telah diperoleh bersama teman satu kelas. Peneliti membimbing siswa dalam diskusi kelas namun ada beberapa siswa yang tidak memperhatikan.

Peneliti memberikan bimbingan kepada siswa untuk menemukan konsep berdasarkan hasil diskusi dengan memberikan pertanyaan-pertanyaan pancingan yang mengarah kepada konsep debit yang berkaitan dengan volume dan waktu. Pertemuan kedua materi yang dipelajari tentang pengukuran volume berdasarkan debit air. Pada kegiatan awal, Peneliti mengawali pembelajaran dengan melakukan apersepsi kepada siswa. Pertanyaan tersebut diantaranya mengulangi materi yang telah dipelajari sebelumnya. Peneliti akan memaparkan hasil belajar kognitif dan afektif siswa yang telah diperoleh pada siklus I sebagai berikut: 


\section{Hasil Belajar Kognitif}

Hasil belajar pada siklus I ini diperoleh pada pertemuan ketiga. Sebanyak 9 siswa dari 14 siswa dinyatakan tuntas, sedangkan jumlah siswa yang belum tuntas adalah 6 siswa. Ratarata hasil tes tersebut adalah 6,13. Persentase hasil belajar siswa pada siklus I sebagai berikut:

Tabel 1. Persentase jumlah siswa yang tuntas belajar pada siklus I

\begin{tabular}{|l|c|c|c|c|}
\hline \multirow{2}{*}{ Kategori } & \multicolumn{2}{c|}{ Pra tindakan } & \multicolumn{2}{c|}{ Siklus I } \\
\cline { 2 - 5 } & Siswa & $\%$ & Siswa & $\%$ \\
\hline Tuntas & 3 & 20 & 8 & 53,33 \\
\hline Belum tuntas & 12 & 80 & 7 & 46,67 \\
\hline Jumlah & 15 & 100 & 15 & 100 \\
\hline
\end{tabular}

Berdasarkan tabel di atas dapat diketahui bahwa sebanyak 8 siswa atau 53,33\% siswa dari seluruh siswa mendapatkan nilai $\geq 65$ dibandingkan data nilai pra tindakan yang hanya 3 siswa atau 20\%, sedangkan jumlah siswa yang belum tuntas adalah 7 siswa atau 46,67\% siswa dari seluruh siswa mendapatkan nilai $\geq 65$. Berdasarkan hasil tersebut dapat dikatakan terjadi peningkatan 26,67\% jumlah siswa yang tuntas belajar dilaksanakan pada siklus I. Perbandingan hasil belajar pada pra tindakan dan Siklus I diperjelas pada diagram batang sebagai berikut:

\section{Perbandingan hasil belajar Pra tindakan dengan Siklus I}

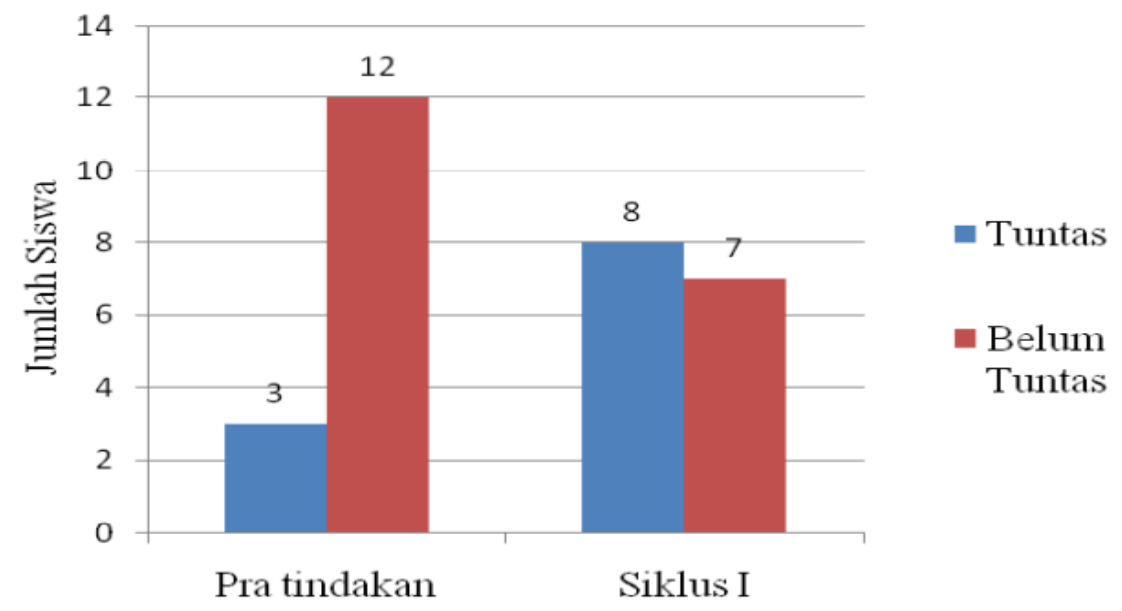

Gambar 1. Perbandingan hasil belajar pra tindakan dengan Siklus I

Hasil belajar Afektif berupa Sikap Siswa dalam proses pembelajaran Hasil observasi sikap siswa pada mata pelajaran Matematika siklus I untuk setiap pertemuan. Berikut ini tabel hasil observasi sikap siswa pada siklus I

Tabel 2. Hasil Observasi Sikap Siswa Siklus I

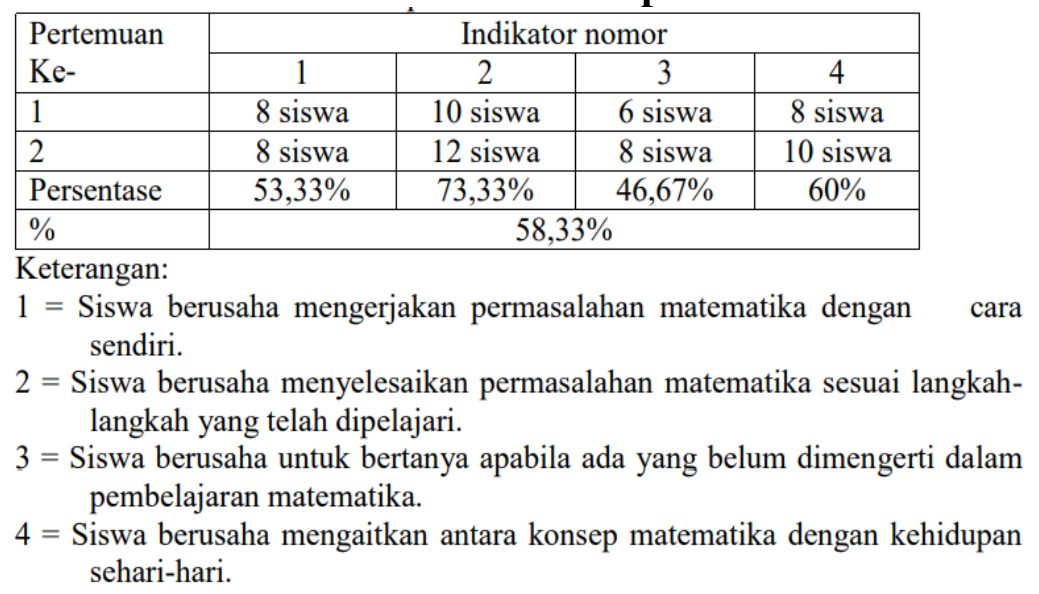


Berdasarkan tabel hasil observasi sikap siswa siklus I di atas, dapat dilihat bahwa dari aspek sikap siswa diperoleh data 53,33\% (dari 15 siswa) telah berusaha mengerjakan permasalahan matematika dengan cara sendiri; 73,33\% (dari 15 siswa) telah berusaha menyelesaikan permasalahan matematika sesuai langkah-langkah yang telah dipelajari; 46,67\% (dari 15 siswa) telah berusaha untuk bertanya apabila ada yang belum dimengerti dalam pembelajaran matematika dan 60\% (dari 15 siswa) telah berusaha mengaitkan antara konsep matematika dengan kehidupan sehari-hari. Dari hasil observasi tersebut, sikap siswa pada mata pelajaran matematika mencapai 58,33\% (dari 15 siswa).

\section{B. Hasil Observasi pada Siklus II}

Observasi yang dilakukan pada siklus II meliputi dua pertemuan. Dari kedua pertemuan tersebut, Peneliti telah melakukan semua aktivitas yang ada dalam lembar observasi. Siklus II dilakukan sebanyak dua kali pertemuan. Pertemuan pertama adalah materi pengukuran yaitu menentukan kecepatan debit air dalam satuan jam/menit. Pada kegiatan awal, Peneliti mengawali pembelajaran dengan mendemonstrasikan kecepatan debit air dalam satuan jam/menit.

Peneliti memberikan pertanyaan dari hasil demontrasi tersebut kepada siswa. Peneliti membimbing siswa untuk menjawab pertanyaan. Setelah mengerjakan tugas Peneliti meminta salah satu kelompok untuk menuliskan jawabannya ke papan tulis dan meminta kelompok lain dengan jawaban berbeda juga menuliskan jawabnya. Peneliti menanggapi jawaban siswa pada hasil diskusi. Peneliti mengaitkan materi debit dengan tangga satuan dan konsep waktu.

Pertemuan kedua adalah materi pengukuran yaitu menentukan volume berdasarkan debit air dalam satuan menit/jam. Peneliti mengawali pembelajaran dengan memberikan masalah kontekstual yang berkaitan dengan materi volume. Peneliti membimbing siswa untuk menjawab masalh kontekstual yang diberikan guru. Setelah mengerjakan tugas meminta salah satu kelompok untuk menuliskan jawabannya ke papan tulis dan meminta kelompok lain dengan jawaban berbeda juga menuliskan jawabnya. Peneliti menanggapi jawaban siswa pada hasil diskusi. Peneliti mengaitkan materi volume dengan tangga satuan volume, konsep waktu dan debit

Selain hasil observasi yang berupa aktivitas guru, peneliti akan memaparkan hasil belajar kognitif dan afektif siswa yang telah diperoleh pada siklus II sebagai berikut:

\section{Hasil Belajar Kognitif}

Hasil belajar pada siklus II ini diperoleh pada pertemuan ketiga. Sebanyak 12 siswa dari 15 siswa kelas VI dinyatakan, sedangkan jumlah siswa yang belum tuntas adalah 3 siswa. Ratarata hasil tes tersebut adalah 7,60. Persentase hasil belajar pada siklus II dapat dilihat pada tabel sebagai berikut.

Tabel 3. Persentase jumlah siswa yang tuntas belajar pada siklus II

\begin{tabular}{|l|c|c|c|c|}
\hline \multirow{2}{*}{ Kategori } & \multicolumn{2}{|c|}{ Siklus I } & \multicolumn{2}{c|}{ Siklus II } \\
\cline { 2 - 5 } & Siswa & $\%$ & Siswa & $\%$ \\
\hline Tuntas & 8 & 53,33 & 12 & 80 \\
\hline Belum tuntas & 7 & 46,67 & 3 & 20 \\
\hline Jumlah & 15 & 100 & 15 & 100 \\
\hline
\end{tabular}

Berdasarkan tabel di atas dapat diketahui bahwa pada siklus II sebanyak 12 siswa atau $80 \%$ siswa dari seluruh siswa mendapatkan nilai $\geq 65$ dibandingkan data nilai siklus I yang hanya 8 siswa atau 53,33\%, sedangkan jumlah siswa yang belum tuntas adalah 3 siswa atau $20 \%$ siswa dari seluruh siswa mendapatkan nilai $\geq 65$. Berdasarkan hasil tersebut dapat dikatakan terjadi peningkatan $26,67 \%$ jumlah siswa yang tuntas belajar dilaksanakan pada siklus II. Perbandingan hasil belajar pada Siklus I dan Siklus II diperjelas pada diagram batang sebagai berikut: 


\section{Perbandingan hasil belajar Siklus I dan}

Siklus II
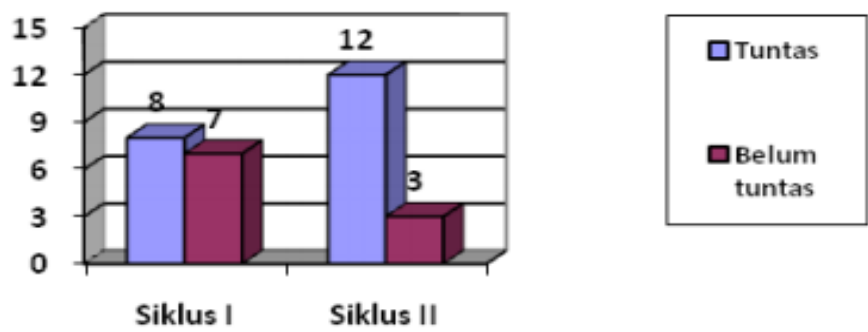

Gambar 2. Peningkatan hasil belajar pada siklus I dan Siklus II

Hasil belajar Afektif berupa Sikap Siswa dalam proses pembelajaran Hasil belajar Afektif berupa Sikap Siswa dalam proses pembelajaran. Berikut ini tabel hasil observasi sikap siswa pada siklus II.

Tabel 4. Hasil observasi sikap siswa Siklus II

\begin{tabular}{|l|c|c|c|c|}
\hline \multirow{2}{*}{$\begin{array}{l}\text { Pertemuan } \\
\text { Ke- }\end{array}$} & \multicolumn{4}{|c|}{ Indikator nomor } \\
\cline { 2 - 5 } & 1 & 2 & 3 & 4 \\
\hline 1 & 11 siswa & 12 siswa & 11 siswa & 10 siswa \\
\hline 2 & 12 siswa & 13 siswa & 12 siswa & 12 siswa \\
\hline Persentase & $76,67 \%$ & $83,33 \%$ & $76,67 \%$ & $73,33 \%$ \\
\hline$\%$ & \multicolumn{5}{|c|}{$77,5 \%$} \\
\hline
\end{tabular}

Keterangan:

$1=$ Siswa berusaha mengerjakan permasalahan matematika dengan cara sendiri.

2 = Siswa berusaha menyelesaikan permasalahan matematika sesuai langkahlangkah yang telah dipelajari.

3 = Siswa berusaha untuk bertanya apabila ada yang belum dimengerti dalam pembelajaran matematika.

4 = Siswa berusaha mengaitkan antara konsep matematika dengan kehidupan sehari-hari.

Berdasarkan tabel hasil observasi sikap siswa siklus II di atas, dapat dilihat bahwa dari aspek sikap siswa diperoleh data 77,67\% (dari 15 siswa) telah berusaha mengerjakan permasalahan matematika dengan cara sendiri; 83,33\% (dari 15 siswa) telah berusaha menyelesaikan permasalahan matematika sesuai langkah-langkah yang telah dipelajari; 76,67\% (dari 15 siswa) telah berusaha untuk bertanya apabila ada yang belum dimengerti dalam pembelajaran matematika dan 73,33\% (dari 15 siswa) telah berusaha mengaitkan antara konsep matematika dengan kehidupan sehari-hari. Dari hasil observasi tersebut, sikap siswa yang berupa aktivitas berusaha berpikir beradsarkan data yang dapat digunakan pada mata pelajaran Matematika mencapai 77,5\% (dari 15 siswa).

\section{Pembahasan Penelitian}

Matematika merupakan salah satu pelajaran yang diajarkan di Sekolah Dasar. Menurut Sri Subarinah (2006) matematika merupakan ilmu tentang pola keteraturan, mulai dari unsur yang tidak didefinisikan ke unsur yang didefiniskan kemudian ke aksioma, dan akhirnya ke dalil. Dalam matematika terdapat sebuah pola yang teratur kemudian dapat disusun menjadi sebuah rumus matematika yang dapat dipelajari oleh semua orang. Dalam mengajarkan matematika di sekolah, guru harus menyadari bahwa setiap siswa memiliki kemampuan yang berbeda-beda dan ada beberapa siswa yang tidak menyenangi pelajaran matematika. Dengan demikian guru hendaknya menyajikan pembelajaran yang aktif dan kreatif sehingga siswa merasa senang dalam belajar matematika. 
Sejalan dengan pendapat tersebut, Sri Subarinah. (2006): 5) menjelaskan bahwa matematika adalah sebuah ilmu pasti yang selama ini menjadi induk dari segala ilmu pengetahuan di dunia. Kemajuan zaman dan perkembangan kebudayaan serta peradaban manusia tidak terlepas dari matematika. Tanpa ada matematika, tentu saja peradaban manusia tidak akan pernah mencapai kemajuan seperti sekarang ini

Penelitian Tindakan Kelas meliputi 2 siklus yang terdiri dari siklus I dan siklus II. Setiap siklus terdiri dari 2 kali pertemuan dan terdiri dari beberapa tahap, yaitu tahap perencanaan, tindakan, observasi, dan refleksi. Pada siklus II tahaptahap yang dilakukan merupakan perbaikan pada siklus sebelumnya. Hasil yang diperoleh pada penelitian ini terdiri dari data tes yang berupa hasil belajar kognitif yang diperoleh melalui tes dan hasil belajar afektif berdasarkan hasil observasi sikap siswa menggunakan Pembelajaran Matematika Realistik.

Hasil dari kedua siklus tersebut digunakan untuk mengetahui peningkatan hasil belajar Matematika dengan menggunakan Pembelajaran Matematika Realistik pada siswa kelas VI Data yang diperoleh sebelum dan setelah dilaksanakan tindakan menunjukkan adanya peningkatan hasil belajar siswa yang ditunjukkan dengan hasil tes yang dipeoleh. Sebelum diterapkanya PMR dalam pembelajaran Matematika, diperoleh sebanyak 3 siswa atau 20\% siswa mendapat nilai $\geq 65$, sedangkan 13 atau $80 \%$ siswa mendapat nilai kurang dari 65 .

Namun setelah pembelajaran melalui PMR pada siklus I dan II diperoleh data bahwa hasil belajar siswa meningkat. Hasil tes siklus I dipeoleh 8 atau 53,33\% dari seluruh siswa mendapat nilai $\geq 65$, sedangkan 7 siswa atau 46,67\% dari seluruh siswa belum mencapai nilai $\geq 65$. Berdasarkan data tersebut dapat dikatakan terjadi peningkatan 33,33\% jumlah siswa yang tuntas belajar pada tindakan siklus I. Kemudian pada hasil tes siklus II menunjukkan 12 atau $80 \%$ dari seluruh siswa tuntas dan 3 siswa atau $20 \%$ siswa yang belum tuntas. Jika dibandingkan dengan prestasi belajar siklus I, mengalami peningkatan $26,67 \%$ jumlah siswa yang tuntas belajar.

Ditinjau dari nilai rata-rata tes yang diperoleh siswa, saat dilakukan tes pra tindakan yaitu 4,47. Nilai rata-rata hasil tes pada siklus I yaitu 6,13 sedangkan nilai rata-rata tes siklus II yaitu 7,60. Berdasarkan data di atas, dapat diketahui bahwa terjadi peningkatan nilai rata-rata siswa dari pra tindakan, siklus I, dan siklus II. Setelah dilaksanakan tindakan siklus I rata-rata hasil tes meningkat 1,66 menjadi 6,13 dibandingkan rata-rata hasil tes sebelum diterapkanya PMR dalam pembelajaran. Kemudian nilai rata-rata hasil tes dari siklus I ke siklus II juga mengalami peningkatan 1,47 menjadi 7,60.

Selain dapat meningkatkan hasil belajar kognitif siswa, pendekatan Pembelajaran Matematika Realistik ini juga dapat meningkatkan hasil belajar afektif berupa peningkatan sikap siswa yang berlangsung di dalam kelas selama pembelajaran berlangsung. Pada saat observasi awal yang dilakukan peneliti pada pembelajaran Matematika di kelas IV, pada saat proses pembelajaran Matematika berlangsung, guru menyampaikan materi dengan ceramah dan sesekali mengajukan pertanyaan kepada siswa. Guru terlihat kurang melibatkan siswa dalam melakukan proses pembelajaran dan cenderung medominasi pembelajaran.

Marsigit (2011:5) Matematika sebagai kegiatan penelusuran pola dan hubungan, Pedoman bagi guru dan siswa dalam pembelajaran Matematika adalah: 1) Memperoleh kesempatan untuk melakukan kegiatan penemuan dan penyelidikan pola-pola untuk menentukan hubungan matematika, 2) Memperoleh kesempatan untuk melakukan percobaan matematika dengan berbagai cara, 3) Memperoleh kesempatan untuk menemukan adanya urutan, perbedaan, perbandingan, pengelompokan, dalam matematika, 4) Memperoleh kesempatan untuk menarik kesimpulan umum (membuktikan rumus), 5) Memahami dan menemukan hubungan antara pengertian matematika yang satu dengan yang lainnya.

Pada siklus I dan II diterapkan pendekatan Pembelajaran Matematika Realistik. Masalah-masalah nyata dari kehidupan sehari-hari digunakan sebagai titik awal pembelajaran matematika untuk menunjukkan bahwa matematika dekat dengan kehidupan sehari-hari. Benda-benda nyata yang akrab dengan kehidupan sehari-hari dijadikan sebagai alat peraga yang dalam penelitian ini alat peraga untuk debit air sehingga siswa menjadi lebih tertarik. Hal 
tersebut senada dengan pendapat Hadi (Nyimas Aisyah dkk, 2007: 7-1) bahwa melalui PMR siswa menjadi lebih tertarik dan senang belajar matematika serta menunjukkan peningkatan hasil belajar yang cukup memuaskan.

Guru juga memberikan kesempatan kepada siswa melalui kegiatan diskusi, sehingga mendorong adanya interaksi antar teman maka pembelajaran memungkinkan siswa bersosialisasi dengan menghargai perbedaan pendapat dan berlatih untuk bekerja sama. Semakin sering dilaksanakan kegiatan diskusi dapat meningkatkan interaksi serta kerja sama. Hal ini menunjukkan adanya peningkatan partisipasi siswa pada setiap siklus, terjadinya peningkatan hasil belajar siswa tersebut merupakan hasil dari pembelajaran melalui PMR yang secara umum berjalan dengan baik seperti yang dilihat dari hasil pengamatan pada saat pembelajaran berlangsung.

Dengan adanya kegiatan atau aktivitas untuk menemukan sendiri konsep matematika akan mendorong siswa untuk berpartisipasi aktif dalam aktivitas pembelajaran. Hal tersebut sesuai dengan pendapat Sugihartono (2007: 109) bahwa pengamatan sangat penting dan menjadi dasar dalam menuntun proses belajar oleh karena itu dalam belajar diupayakan siswa harus mengalami sendiri dan terlibat langsung secara realistik dengan obyek yang dipelajarinya. Berdasarkan hasil pengamatan yang dilakukan oleh peneliti sebagai observer dapat dilihat bahwa siswa terlihat lebih aktif dari sebelum dilakukan tindakan. Hal tersebut dikarenakan pada pembelajaran Matematika Realistik guru memberikan pengalaman langsung kepada siswa dengan melakukan berbagai kegiatan yang menuntut siswa untuk aktif secara kognitif, afektif dan psikomotor. Untuk kemampuan kognitifnya siswa diberi tugas. Hal tersebut dilakukan melalui diskusi kelompok. Setelah itu, guru memberikan kesempatan kepada masing-masing kelompok untuk mempresentasikan hasil diskusinya di depan kelas. Untuk mengulangi materi yang telah dipelajari guru memancing siswa dengan pertanyaan-pertanyaan singkat sehingga siswa mampu menyimpulkan sendiri materi yang telah dipelajarinya dan mampu membangkitkan motivasi siswa dalam belajar.

\section{KESIMPULAN}

Pembelajaran siklus I dan II, guru menggunakan masalah kontekstual yang berkaitan dengan materi untuk memulai pembelajaran, siswa menggunakan mendiskusikan, menemukan konsep berdasarkan hasil diskusi kemudian memperkenalkan prosedur baku untuk menyelesaikan masalah menggunakan rumus dan dalam pembelajarannya mengaitkan konsep lain dalam matematika yang berhubungan dengan materi. Jadi sebelum siswa langsung mendapatkan rumus untuk menyelesaikan masalah maka terlebih dahulu siswa telah telibat langsung menggunakan alat peraga, melakukan pengamatan dan diskusi kelompok dalam menemukan konsep sehingga selain membuat siswa lebih aktif maka apa yang dipelajari akan bertahan lama pada memori siswa. Peningkatan sikap siswa tersebut sejalan dengan peningkatan hasil tes yang diperoleh. Hasil penelitian menunjukkan bahwa hasil belajar dapat meningkat setelah diberi tindakan melalui Pembelajaran Realistik. Hasil belajar kognitif pada pra tindakan menunjukkan bahwa sebanyak 3 siswa (20\%) telah mencapai KKM kemudian pada siklus I meningkat menjadi 8 siswa $(54,30 \%)$ dan pada siklus II meningkat menjadi 12 siswa (80\%). Hasil rata-rata sikap siklus I mencapai 59,30\% sedangkan siklus II diperoleh hasil rata-rata sikap sebesar 79,5\%. Dengan demikian, Pembelajaran Matematika Realistik dapat meningkatkan hasil belajar Matematika siswa kelas IV SD Negeri 34 Sungai Belidak.

\section{DAFTAR PUSTAKA}

Aisyah., Nyimas., dkk. (2007). Pengembangan Pembelajaran Matematika SD. Jakarta: Depdiknas Dirjen Dikti Direktorat Ketenagaan.

Marsigit. (2011). Metodologi pembelajaran matematika. Makalah disajikan pada kunjungan guru-guru SD Wilayah Binaan III Kecamatan Kemayoran Jakarta Pusat di FMIPA $U N Y$. 
Prihandoko.,C.,A. (2006). Memahami konsep matematika secara benar dan menyajikannya dengan menarik. Jakarta: Depdiknas Dirjen Dikti Direktorat Ketenagaan.

Sapri. (2018). Perkembangan Psikologi Siswa dalam Pendidikan Islam. Priceedings ABKIN: International Conference on Guidance and Counseling (ICGC). Multicultural Guidance and Counseling

Siswoyo.,Dwi., dkk. (2007). Ilmu Pendidikan. Yogyakarta: UNY Press.

Subarinah., Sri. (2006). Inovasi Pembelajaran Matematika SD. Depdiknas: Jakarta.

Sugihartono, dkk. (2007). Psikologi Pendidikan. Yogyakarta: UNY Press

Tarigan. (2006). Pembelajaran Matematika Realistik. Jakarta: Depdiknas.

Wijaya., Ariyadi. (2012). Pembelajaran Matematika Realisik. Yogyakarta: Graha Ilmu. Daitin 